Прочность сварных соединений и деформации конструкций : учебное пособие. Москва : Высшая школа, 1982. 272 с., ил.

5. Винокуров В.А. Сварочные деформации и напряжения. Методы их устранения. Москва : Машиностроение, 1968. 236 с., ил.

6. URL: www.weldering.com

7. Марочник сталей и сплавов.

URL: www.splav-kharkov.com

\title{
НАУКОВА ШКОЛА 3 БАЛІСТИЧНОГО ПРОЕКТУВАННЯ ЛІТАЛЬНИХ АПАРАТІВ НА КАФЕДРІ ПРОЕКТУВАННЯ ТА КОНСТРУКЦЙ І В НДЛ РАКЕТНО-КОСМІЧНОЇ ТЕХНІКИ НДІ ЕНЕРГЕТИКИ: ІСТОРІЯ ТА СЬОГОДЕННЯ
}

\author{
Л. Г. Дубовик
}

Дніпровський національний університет імені Олеся Гончара, пр. Гагаріна, 72, м. Дніпро, 49010, Україна, e-mail: bechkekarolina@gmail.com

Розглянуто історію формування й сьогодення одного з наукових напрямків кафедри проектування та конструкцій і науково-дослідної лабораторії ракетно-космічних систем НДІ енергетики, втілення результатів у практику. Відображено вагомий внесок у розвиток цього напрямку професора Дроня Миколи Михайловича.

Ключові слова: наукова школа, балістичне проектування, техногенне засмічення навколоземного космічного простору.

The history of creation and the present one of scientific directions of chair of designing and designs and research laboratory of rocket-technical engineering of scientific research institute of power, introduction of results in practice are considered. The powerful contribution to development of this direction of professor Dronja Nikolay Mihajlovicha is noted.

Keywords: school of thought, ballistic designing, technogenic clogging of a near-earth space.

Рассмотрена история создания и настоящее одного из научных направлений кафедры проектирования и конструкций и научно-исследовательской лаборатории ракетно-космических систем НИИ энергетики, внедрение результатов в практику. Отмечен весомый вклад в развитие этого направления профессора Дроня Николая Михайловича.

Ключевые слова: научная школа, баллистическое проектирование, техногенное засорение околоземного космического пространства.

Ця наукова школа виникла на кафедрі проектування та конструкцій літальних апаратів у 60-ті роки на основі наукових досліджень, проектно-конструкторських та експериментальних робіт зі створення артилерійських та ракетних систем під керівництвом завідуючого кафедрою професора, доктора технічних наук, заслуженого діяча науки i техніки Дупліщева Михайла Іларіоновича та доцента, кандидата, а в подальшому доктора технічних наук Натушкіна Володимира Федоровича.

3 початку 60-х років наукова робота кафедри здійснювалася у двох напрямках: конструювання й будівельна механіка ракет, який очолював професор M. I. Дупліщев, та балістика [1]. Балістика (C) Дубовик Л.Г., 2018 керованих балістичних ракет (КБР) розвивалася під науковим керівництвом декана фізико-технічного факультету, професора, кандидата технічних наук Г. Д. Макарова, а балістика балістичних некерованих ракетних снарядів (БНРС) під керівництвом проф. М. І. Дупліщева. Також набирали перспективу наукові напрями, які очолили наукові керівники госпдоговірних НДР доценти А. С. Сзовітов (Герметичність фланцевих та інших з'єднань КРБ), В. М. Ляпін (Проектування пневмо-гідравлічних систем), В. I. Перлик (Надійність складних систем), Г. В. Можаєв (Синтез орбітальних структур супутникових систем).

Ще більш різноманітною стала наукова тематика кафедри 3 приходом 
у 1969 році доцента $\quad$ В. Ф. Натушкіна. Тривалий час він займався будівельною механікою ракет і отримав низку серйозних наукових результатів, готував до захисту докторську дисертацію, але через труднощі продовження цих робіт i, 3 іншого боку, внаслідок стійкого інтересу до динаміки літальних апаратів, який сформувався ще 3 часу пілотування ним бойових літаків, перейшов до динаміки просторового руху ЛА різного призначення, їх стійкості та керованості 3 врахуванням впливу перехресних зв'язків.

Завдяки створеному тандему M. I. Дупліщев - $\quad$ В. Ф. Натушкін, поєднанню їх взаємодоповнюючих якостей на кафедрі сформувався цікавий науковий напрям 3 теорії літальних апаратів, практики їх проектування і конструювання. При цьому професор М. I. Дупліщев володів різнобічними теоретичними знаннями, значним досвідом конструкторської і промислової діяльності зі створення артилерійських і ракетних систем, a доцент В.Ф. Натушкін глибокими теоретичними знаннями, найскладнішими математичними методами, умінням постановки і здійснення складних фізичних експериментів.

Обидва відрізнялися виключною працездатністю, самовіддачею. Досить зазначити, що проф. М. I. Дупліщев паралельно проводив особисті дослідження й розробки в інших областях, у тому числі 3 альтернативних підходів до існуючої теорії відносності, що надалі стала його головною тематикою. В. Ф. Натушкін, по суті, паралельно проводив особисті дослідження в області динаміки просторового руху, стійкості й керованості літаків 3 врахуванням впливу перехресних зв'язків, побудови нових математичних моделей руху, критеріїв стійкості й керованості, розробки оптимальних законів керування на екстремальних режимах польоту. Згодом в його докторській дисертації було вирішено проблему розробки теоретичних основ забезпечення стійкості й керованості атмосферних літальних апаратів (ЛА) в екстремальних умовах, що дозволило проектувати технічні засоби для виявлення й запобігання критичним динамічним яви- щам: штопора, звалювання, параметричного розкачування високоманеврених літаків.

Досвід розробки артилерійських систем на Уралі в роки війни під керівництво видатного творця цих систем $Ф$. Ф. Петрова обумовив висунення проф. М. І. Дупліщевим ідеї гіромоторної стабілізації ракет, передусім некерованих. Початок теоретичних досліджень конструкторської розробки припадає на 1963 рік, коли майже одночасно було подано першу заявку на винахід і прийнято рішення Радою міністрів СРСР 3 розгортання комплексу робіт. За заказом промисловості було виконано госпдоговірну науково-дослідну роботу, у той час одну з найбільш великих за обсягом фінансування, яка поєднала зусилля низки вчених ДДУ. Пізніше ці питання було викладено в низці науково-технічних звітів та статей, а потім у навчальному посібнику «Основы проектирования баллистических неуправляемых ракетных снарядов», який був виданий в 1974 р. 3 грифом Мінвузу СРCР.

Гіромоторна стабілізація, яка здійснювалася не за рахунок обертання всієї ракети, а спеціального ротора (гіромотора) або іншої частини ракети, дозволяла регулювати величину кінетичного моменту обертання, значно підвищити початкову стійкість, зменшити розсіювання БНРС, що було підтверджено у ході випробувань партій експериментальних БНРС, оснащених гіромотором з електричним приводом.

Кінограми пусків партії 320 шт. стоміліметрових експериментальних снарядів 3 електричними гіромоторами (довжина 15 калібрів, початкова маса 42 кг, дальність 15 км), що були отримані за допомогою швидкісного кіноапарата, свідчили, по суті, про ідеальний схід 3 напрямних. Ймовірне відхилення в боковому напрямку випробуваної партії некерованих ракет через недосконалість пускової установки було зменшено більш ніж у 3,5 раза. Як стало відомо, гіромоторна стабілізація була використана далі на БРНС США «Литтл Джон». 
Запуск експериментальних БНРС разом 3 ідеальним сходом 3 напрямних показали також зростання нестійкості у вершині траєкторії й на спадній іiі гілці, що було обумовлено суперечливістю умов стійкості на активній ділянці й у вершині траєкторії. Наступне зниження розсіювання некерованих ракет, що стабілізувалися обертанням, та розширення сфери їх застосування пов'язано 3 необхідністю подолання суперечливості між критеріями стійкості, для чого згодом було розроблено теоретично й експериментально обгрунтований новий спосіб стабілізації обертових ракет 3 прикладанням так званого антинутаційного моменту. Потім були госпдоговірні НДР, у яких розвивалися прикладні аспекти теоретичних основ гіростабілізації стосовно різноманітних типів ЛА.

Пізніше, у 70-х роках, додався новий об’єкт дослідження - дослідницькі ракети (ДР), які використовувалися для вирішення різних задач метеорології, геофізики, випробування й відпрацювання систем різноманітних ЛА. Обертання цих ракет по крену, метою якого від самого початку було зменшення впливу ексцентриситетів маси, форми й тяги, передається в напрямних спірального типу, а також за рахунок косопоставлених стабілізаторів i диференціального відхилення елеронів. Це обертання перетворює ракету в цікавий об'єкт з погляду поєднання двох способів стабілізації. На атмосферній дільниці вона стабілізується аеродинамічним способом, а при виході з атмосфери гіроскопічні ефекти стають переважаючими, i ракета стабілізується обертанням. Незважаючи на різноманіття конструкцій ДР і задач, що виникають при їх конструюванні, виділяються два головних напрямки удосконалення кутової стабілізації. Перший напрямок пов'язаний 3 підвищенням точності розрахунку точок падіння й зниженням розсіювання ракет для мінімізації площі зони, що відчужується. Інформативність ракетних експериментів $\mathrm{i}$ рух 3 великою амплітудою коливання $\epsilon$ несумісними, і удосконалення стабілізації ДР, їх головних частин та інших цільових елементів на ділянці вимірювань набуває важливого значення, чому й присвячені роботи другого напрямку.

У 1970-1972 pp. було виконано дослідження за цією тематикою для Іжевського механічного заводу, а з 1973 p. наступив тривалий період інтенсивного й плідного співробітництва кафедри 3 провідними науковими й проектноконструкторськими організаціями: НBO «Тайфун», НBО «Планета», Інститутом прикладної геофізики, ЦАГІ, Інститутом льотних випробувань, Московським інститутом теплотехніки, МДУ, MAI, MBТУ ім. Баумана. Багаторічне співробітництво продовжувалося завдяки ініціативі відомих вчених та конструкторів, керівників великого напряму 3 розробки й експлуатації вітчизняних дослідницьких ракет.

Було виконано цикл досліджень 3 динаміки просторового руху й розробок 3 кутової стабілізації ДР та відокремлюваних функціональних елементів на траєкторії польоту, актуальність яких була обумовлена необхідністю підвищення інформативності геофізичних і прикладних ракетних експериментів 3 національних міжнародних програм дослідження верхньої атмосфери та космічного простору, а також відповідно до важливих рішень уряду. Розроблено й науково обгрунтовано методи виявлення й запобігання критичним режимам кутового руху ракет - таких як коливальне розгойдування, синхронізація й обертовий резонанс, відпрацювання впливу вітру.

Потім було проведено дослідження 3 визначення просторового положення на ділянці вимірювань, селекції параметрів метеорологічних ракет для зниження розсіювання траєкторних параметрів, динамічної стійкості просторового руху, оптимізації наземного обладнання.

У 80-х роках плідним було співробітництво кафедри 3 Інститутом льотних випробувань (м. Жуковський) зі створення принципово нового датчика просторового положення літака відносно потоку на базі винаходів доц. В. Ф. Натушкіна і М. М. Дроня. У 1987 році дослідницькі випробування експериментального зразка датчика в 
дозвуковій аеродинамічні трубі, які було проведено 3 участю відомих спеціалістів інституту, підтвердили перспективність нової аеродинамічної й вимірювальної схеми, принципу діï, а також працездатність випробувального зразка на дозвукових швидкостях.

Внаслідок зародження й розвитку на кафедрі проектування та конструкцій наукового напряму 3 теорії польоту під керівництвом проф. М. І. Дупліщева та доцента В.Ф. Натушкіна у рамках виконання госпдоговорів 3 проектноконструкторськими організаціями було здійснено чимало наукових досліджень, конструкторських розробок і впроваджень результатів на конкретних зразках ракетної техніки.

Згодом, у 90-х роках, на основі цього наукового напряму кафедри сформувалась тематика, що належить до класичної зовнішньої балістики, зокрема, третьої задачі балістики, присвяченій стійкості руху відносно центра мас, кутової стабілізації. Очолив цю тематику д.т.н., професор Дронь Микола Михайлович.

Під керівництвом М. М. Дроня внаслідок виконання низки НДР, що координувались Міністерством освіти і науки України, було розроблено й науково обгрунтовано нові принципи вимірювання параметрів набігаючого потоку й параметрів руху високоманеврених літальних апаратів відносно набігаючого потоку в системі координат, пов'язаній 3 рухомою площиною просторового кута атаки. Побудовані нові схеми вимірювання втілено в численні технічні рішення, двом 3 яких надано ім'я автора: «Спосіб кутової стабілізації обертових ЛА Дроня» [2] і «Пілон-синхронізатор Дроня» [3].

Основні наукові роботи і винаходи М. М. Дроня стосуються фундаментальних та прикладних проблем створення i використання ракетно-космічної і авіаційної техніки. Він розробив теоретичні основи і методи проектування систем кутової стабілізації ЛА на базі теорії синхронізації обертальних та коливальних рухів і створення стабілізаційних моментів радіальної корекції.
У цілому результати, що відображені у одноосібній монографії «Кутова стабілізація обертових літальних апаратів», статтях, матеріалах конференцій, винаходах, утворили науковий напрямок у балістиці літальних апаратів, забезпеченні стійкості їх руху, зробили певний внесок у теорію i практику проектування систем кутової стабілізації літальних апаратів.

Цикл його теоретичних досліджень i конструкторських розробок зі створення методів i технічних засобів кутової стабілізації та орієнтації некерованих дослідницьких ракет і відокремлюваних функціональних елементів було впроваджено у 80-х роках у практику НВО «Тайфун» та інших організацій Держкомітету 3 гідрометеорології та охорони навколишнього середовища СРСР під час виконання державних i міжнародних програм вивчення верхньої атмосфери та космічного простору, що сприяло підвищенню інформативності геофізичних і прикладних експериментів.

Микола Михайлович вважає, що йому в житті дуже пощастило, оскільки свого часу він брав участь у програмі створення єдиної системи державного моніторингу 3 дослідження атмосфери. Для цього використовувалися ракети, супутникові системи. Вчений брав безпосередню участь у розробці метеорологічних ракет, які зондували атмосферу на висоті 200-250 км. Його наукові інтереси тісно пов'язані 3 Обнінським центром, де були зосереджені науково-дослідні інститути i проектноконструкторські організації систем гідрометеорології.

У співавторстві 3 професором M. В. Поляковим i к.т.н. В. С. Легезою М. М. Дронь удостоєний звання лауреата премії НАН України ім. Янгеля за цикл наукових робіт та винаходів 3 гідрогазодинаміки й динаміки польоту літальних апаратів. Ці результати впроваджено в ДКБ «Південне» при створенні нових зразків ракетно-космічної техніки та в ДНУ при підготовці фахівців для ракетно-космічної галузі.

У співпраці 3 керівниками та співробітниками галузевої науководослідної лабораторії технології 
виробництва друкованих плат ДНУ Микола Михайлович виконував наукові дослідження та розробляв технології i технологічне устаткування для виготовлення ультратонкої гальваностійкої та нагрівостійкої мідної фольги на металевому носії для промислового виробництва фольгованих діелектриків для прецизійних друкованих плат радіоелектронної апаратури аерокосмічної галузі.

Результати опубліковано і захищено авторськими свідоцтвами СРСР та патентами України. За роботи в галузі створення новітніх технологій ультратонкої мідної фольги та пї промислове впровадження на підприємствах СРСР у 1990 році його удостоєно звання лауреата премії Ради Міністрів СРСР.

М. М. Дронь багато уваги приділяв питанням екології та біосферології, будучи академіком Екологічної академії наук України. Його наукові інтереси тісно перепліталися 3 проблемами біосфери. У своїх бесідах зі студентами, аспірантами, викладачами, виступах по радіо й телебаченню вчений синтезував свої думки на проблемах наявності у всесвітньому просторі такого дивовижного феномена, як життя, розум, людина.

Він був членом редакційних колегій міжнародних журналів «Екологія i ноосферологія», «Грунтознавство».

До наукових інтересів М. М. Дроня слід віднести також питання захисту інтелектуальної власності, формування нормативно-правової бази наукової, науково-технічної та інноваційної політики в системі вищої школи, що висвітлено в наукових, навчальних i методичних роботах.

Перебуваючи на посаді проректора 3 наукової роботи ДНУ з 2000 по 2011 рр., Микола Михайлович доклав значних зусиль у справу розвитку науки та відомих наукових шкіл університету, досягнення результатів світового рівня, їх впровадження в навчальний процес i виробництво, а також у підготовку висококваліфікованих наукових та педагогічних кадрів. За цей час обсяг фінансування науки ДНУ виріс у п'ять разів.

Однією 3 важливих проблем науки, вважає вчений, $є$ збереження нашої планети від випадкового падіння на іiі поверхню космічних тіл: комет, астероїдів, метеоритів. На думку Миколи Михайловича, вже сьогодні людина має можливість розраховувати траєкторію падіння на Землю випадкових природних космічних об'єктів, а сучасні протиракетні системи здатні застерегти від падіння на Землю невеликих астероїдів, метеоритів, а в подальшому i небезпечних для Землі комет.

Далекий космос, крім того, впливає на погодні умови Землі.

Сьогодні Дронь Микола Михайлович $\epsilon$ науковим керівником НДЛ ракетнокосмічної техніки Інституту енергетики, діяльність якої спрямована на вирішення актуальної проблеми сучасності - боротьбі 3 космічним сміттям техногенного походження на низьких навколоземних орбітах.

Він очолює напрями досліджень, які пов'язані з розробкою принципів побудови космічних транспортних систем для запобігання засміченню навколоземного простору: теоретичні та експериментальні дослідження принципів побудови космічних апаратів (КА) для збору космічного сміття, дослідження питань застосування існуючих засобів відводу космічних об'єктів 3 низьких навколоземних орбіт, питання розробки електроракетних двигунів i датчиків набігаючого потоку для високоманеврених KA.

Під керівництвом д.т.н. В. В. Смця, що $є$ одним 3 провідних фахівців НДЛ, проводяться теоретичні та експериментальні дослідження автофажної ракети-носія (РН), до яких належать вибір основних проектних параметрів $\mathrm{PH}$ різними конструктивними схемами подачі компонентів палива до двигунної установки, визначення особливостей функціонування моделі двигуна, експериментальне опрацювання нових принципів проектування, зокрема 
застосування

пульсуючих

двигунних

установок.

К.т.н. Т. В. Лабуткіна працюе над вирішенням задач прогнозу безпечних зближень i механічних зіткнень між орбітальними тілами, зокрема задачі забезпечення безпечного функціонування космічної техніки в навколоземному космічному просторі, аналізу екології навколоземного космосу й прогнозу сценаріїв його заповнення орбітальними об'єктами та ін.

К.т.н. О. В. Голубек на основі систематизації характеристик космічних апаратів, що закінчили термін активного функціонування, i каталогізованих космічних об'єктів (КО) здійснює моделювання процесів відводу цих КА й КО з навколоземних орбіт.

К.т.н. П. Г. Хорольський займався вивченням механіки космічного польоту, балістикою ракет та точністю вимірювань орієнтації літальних апаратів відносно набігаючого потоку.

К.т.н. А. В. Хитько вивчав питання можливості й доцільності застосування ЕРД в активних системах відводу космічних апаратів і об'єктів на безпечні орбіти.

К.т.н. Л. В. Накашидзе працює над підвищенням енергоефективності сонячних фотоелектричних установок при одночасному зниженні питомої вартості енергії, яка використовується в системах енергозабезпечення ЕРД.

За виконаними проектами, що фінансувалися 3 держбюджету України, «Дослідження принципів побудови космічних літальних апаратів для збору космічного сміття та оцінки його цільової ефективності», «Прогнозування тактикотехнічних характеристик космічних апаратів для збору космічного сміття на базі існуючих ракет-носіїв», «Основи створення активних систем відводу космічних об'єктів із застосуванням електроракетних двигунів», «Дослідження принципів побудови транспортних космічних систем в умовах запобігання засміченню навколоземного космічного простору», та проекту «Закономірності функціонування комбінованих засобів очищення орбіт 3 врахуванням динаміки навколоземного середовища» отримано такі результати.

Розроблено принципи створення активних, пасивних та комбінованих засобів видалення дрібного й великогабаритного космічного сміття 3 низьких навколоземних орбіт.

Показано, що для видалення дрібного сміття найбільш доцільним $є$ використання спеціальних КА - космічних сміттезбирачів на основі тонкостінної великогабаритної експонованої конструкції. Частина сміття при зіткненні з нею випаровується, частина захоплюється, а частина, яка залишилася, гальмується й згорає в щільних шарах атмосфери Землі. Обгрунтовано, що для маневрування такого космічного апарата найдоцільнішим буде застосування електроракетної рушійної установки на базі стаціонарного плазмового двигуна.

Для видалення великогабаритного космічного сміття запропоновано сміттєзбирач, який після захвату великих космічних об'єктів зводить низькоорбітальне сміття до щільних шарів атмосфери Землі, а високоорбітальне переводить на орбіту захоронення. Маневрування такого сміттєзбирача доцільно здійснювати із застосуванням ракетного двигуна на пастоподібному паливі з глибоким дроселюванням тяги.

3 метою запобігання утворенню нового космічного сміття розглянуто можливі системи відводу КА й КО 3 низьких навколоземних орбіт та транспортні космічні системи їх виведення, що не засмічують земну поверхню й навколоземне космічне середовище. Визначено вимоги до цих систем, сформульовано принципи їх побудови та надано балістичне забезпечення траєкторій відводу великих космічних об'єктів 3 врахуванням динамічно змінюваної верхньої атмосфери.

За проведеними дослідженнями й розрахунками як найбільш перспективну запропоновано комбіновану систему відводу космічних апаратів й об'єктів на базі двигунної установки й аеродинамічного вітрильного пристрою. Двигунна установка забезпечує формування еліптичної орбіти відводу 3 
перигеєм у верхніх шарах атмосфери Землі, a аеродинамічне вітрило - поступове зниження швидкості за рахунок впливу на об’єкт відводу аеродинамічного опору атмосфери. При цьому ефективність вітрильного пристрою багато в чому залежатиме від стану верхньої атмосфери Землі.

Надано

експериментальне теоретичне й обгрунтування конструктивно-компонувальної схеми автофажної (спалимої) ракети-носія, бакова оболонка якої виконана із полімерного матеріалу й використовується як основне пальне, та обгрунтовано доцільність застосування таких РН для доставки систем відводу на навколоземні орбіти.

Багаторічні доробки наукової школи в розробці принципів та елементів конструкції датчика потоку, що є важливим елементом для аерокосмічних літальних апаратів, дозволили використати їх для проектування пристроїв контролю параметрів набігаючого потоку, які можуть бути застосовані в космічних транспортних системах.

Характерною рисою отриманих результатів $\epsilon$ ïx новизна, яка полягає у врахуванні на енергетичні витрати процесу відводу об'єктів космічного сміття динаміки атмосфери та застосуванні для виведення комбінованої системи відводу. автофажної ракети-носія.

У зв'язку з їх актуальністю результати досліджень схвалено Державним підприємством «Конструкторське бюро «Південне» ім. М.К. Янгеля», Інститутом технічної механіки НАНУ i НКАУ, Національним Центром аерокосмічної освіти молоді ім. О.М. Макарова, які передбачають їх використання в перспективних розробках 3 вирішення проблеми очищення навколоземного простору, застосування в проектах НКАУ, зокрема в розробці молодіжних супутників.
Наукову роботу М. М. Дронь успішно поєднує 3 плідною педагогічною діяльністю. Підготував низку навчальних посібників, у тому числі 3 грифом Міністерства освіти i науки України: «Основи патентознавства», «Правовий захист інтелектуальної власності вищого закладу освіти», «Основи теорії захисту інформації», «Навколоземний простір і технічні засоби для його освоєння». У 1998 р. Микола Михайлович нагороджений знаком «Відмінник освіти України», $\epsilon$ Академіком Академії наук Вищої школи України.

Різнобічні досягнення видатного вченого Миколи Михайловича Дроня принесли йому широке визнання не тільки в Україні, але й далеко за ії межами.

Понад 300 наукових та науковометодичних праць, серед яких 4 монографії, 10 навчальних посібників, більше 30 доповідей на конференціях, у тому числі міжнародних, 70 винаходів, що захищені авторськими свідоцтвами СРСР та патентами України, отримали вітчизняне та міжнародне визнання. Згідно 3 наказом Державного департаменту інтелектуальної власності від 28.08.2006 р. Миколі Михайловичу вручено нагрудний знак «Творець» за № 91.

\section{Бібліографічні посилання}

1. Дронь Н.М. Развитие теории полета и еe приложений на кафедре проектирования и конструкций. Вісник Дніпропетровського начіонального університету: Серія Ракетно-космічна техніка. 2001. Вип. 5. С. 30-37.

2. Спосіб кутової стабілізації обертових ЛА Дроня: пат. 63 Україна. Опубл. 28.03.2002.

3. Пілон-снхронізатор Дроня: пат. 88128 Україна. № a 200714134; заявл. 17.12.2007; опуб. 10.09.2009, Бюл. № 17.

Надійшла до редколегії 03.08.2018 p 